\title{
Research on Ghinese Family Businesses: Perspectives
}

\author{
Xin Chun Li, ${ }^{1}$ Ling Chen, ${ }^{2}$ Jess H. Chua,,${ }^{2,3,4}$ \\ Bradley L. Kirkman, ${ }^{5}$ Sara Rynes-Weller, ${ }^{6}$ and \\ Luis Gomez-Mejia ${ }^{7}$ \\ ${ }^{1}$ Sun Yat-sen University, China, ${ }^{2}$ Zhejiang University, China, ${ }^{3}$ University of Calgary, Canada, \\ ${ }^{4}$ University of Lancaster, UK, ${ }^{5}$ North Carolina State University, USA, ${ }^{6}$ University of Iowa, USA, \\ and ${ }^{7}$ University of Notre Dame, USA
}

ABSTRACT This introduction traces the disappearance of Chinese family businesses from 1949 to 1978, their revival since then, and their future challenges. It then summarizes the three papers included in this Special Issue and proposes an agenda for family business studies in China. The article first focuses on the nonmarket social and political network strategies that these family-centered business organizations have had to adopt in order to overcome the difficulties they faced in accessing opportunities and resources as a result of Chinese culture's traditional low esteem for merchants and the government's continuing preference for a state-dominated economy. Family firms have so far been able to grow disproportionately rapidly in China's economy because, by leveraging the shared interests and dedication of immediate and extended family members, they have been able to achieve lower cost and higher efficiency, respond quickly to market changes, and expand social and political networks. These nonmarket strategies, however, also have a dark side. Furthermore, as the liberalization of China's economy deepens, competition must rely critically on market strategies such as innovation, alliances, and internationalization. The proposed research agenda addresses these future challenges as well as some research questions unique to Chinese family businesses.

KEYwORDs agency, charitable donations, China, family business, internationalization, nonmarket strategies

\section{INTRODUGTION}

Since economic reforms began in China in 1978, privately-operated enterprises (POEs), as opposed to state-operated enterprises (SOEs), have been developing for more than thirty-seven years. Over this period, POEs have contributed significantly to China's social and economic development (Tsui, Bian, \& Cheng, 2006). By 2012, $68.3 \%$ of business entities in China were POEs (National Bureau of Statistics, 
2014). Xu (2010) estimated that POEs controlled 70\% of the assets in the industrial and service sectors. Most of these POEs were organized around the family, with the family owning, governing, or managing the business (Tsui et al., 2006). Thus, research on the issues, challenges, and future development of this large segment of China's economy is of great importance for understanding China's future economic and social development.

Many of the research issues facing scholars of Chinese family businesses ${ }^{[1]}$ are similar to those faced by researchers on family business in other parts of the world: goals, governance, succession, professionalization, family-business conflict, strategic management, human resource management, innovation, and determinants of performance (De Massis, Sharma, Chua, \& Chrisman, 2012). However, some issues may be unique to China, and other issues exist for all family firms but pose distinctive challenges for those operating within China's particular political, social, and economic structure. To date, relatively little study has taken place on how the changing societal values in combination with the evolving institutions in the past thirty-seven years of economic liberalization have influenced past development and will influence future transformations of the family-centered form of business organization in China. For example, China's one-child policy and its recent relaxation surely will have implications for succession at family firms. ${ }^{[2]}$ Studying the goals that family founders pursued through intrafamily succession and the choices made in the face of limited successor possibilities can yield valuable insights into the psychological, sociological, and economic foundations of those goals and their implications for family firm behavior and performance. Another example is the co-evolution of China's institutions and family firms, a phenomenon that is not happening elsewhere. Changes in market-oriented institutions are affecting family firm behavior and performance, and, at the same time, family firm owners, through their recently elevated political status and participation in the political process, are influencing the development of China's social, economic, and political institutions.

Hence, the purpose of this Special Issue of MOR is to help shed light on the issues and challenges facing family businesses in China and to encourage more research about Chinese family firms. The research will greatly enhance our understanding of the present and future role of family businesses in the Chinese economy, an economy that in October 2014 the International Monetary Fund (International Monetary Fund, 2014) determined as the largest in the world in purchasing power parity terms and is expected to be so in market exchange rate terms by 2032 (Hawksworth \& Tiwari, 2011). It should also provide fertile ground for testing the robustness of concepts and evidence that comes from research focused predominantly on family firms in developed countries.

\section{EVOLUTION OF GHINESE FAMILY FIRMS SINGE 1949}

The role and status of POEs in China since 1949 have undergone dramatic changes as a result of the evolution of the country's unique communist politico-economic 
Table 1. Chronology of changes in the role and status of private enterprises in China since 1949

\begin{tabular}{|c|c|}
\hline Period & Development \\
\hline 1949-1952 & $\begin{array}{l}\text { New government allows the operation of private enterprises. As a result, by the end } \\
\text { of } 1949 \text { private business is responsible for } 48.7 \% \text { of total GDP. }\end{array}$ \\
\hline $1953-1956$ & $\begin{array}{l}\text { The government's transition to socialism transforms all private businesses into joint } \\
\text { state-private enterprises managed by the private owners. }\end{array}$ \\
\hline $1957-1966$ & $\begin{array}{l}\text { Through purchases or takeovers, joint state-private enterprises are transformed into } \\
\text { socialist state-owned enterprises (SOEs). }\end{array}$ \\
\hline 1967-1978 & Nearly all means of production are owned and controlled by the state. \\
\hline 1979-1992 & $\begin{array}{l}\text { Beginning with the creation of township and village enterprises (TVEs), China } \\
\text { began to reform its economy, however, 'private business' was still taboo. The first } \\
\text { generation of entrepreneurs takes over managerial control of the TVEs or small } \\
\text { SOEs but does not own these enterprises in name and has to operate in a } \\
\text { nominally socialist fashion. }\end{array}$ \\
\hline 1992-1999 & $\begin{array}{l}\text { In } 1992 \text { the government's new doctrine becomes 'Building socialism with Chinese } \\
\text { characteristics': although private businesses are no longer taboo, they still lack } \\
\text { legal status. }\end{array}$ \\
\hline 1999 & $\begin{array}{l}\text { The National People's Congress (NPC) amends the constitution to legally recognize } \\
\text { privately owned enterprises. }\end{array}$ \\
\hline 2002 & $\begin{array}{l}\text { Business people become eligible for membership in the Chinese Communist Party, } \\
\text { election to the NPC, and appointment as political advisors to the government. }\end{array}$ \\
\hline 2004 & $\begin{array}{l}\text { The constitution is amended to recognize that 'Citizens' lawful private properties } \\
\text { are inviolable'. }\end{array}$ \\
\hline
\end{tabular}

philosophy, as summarized in Table 1. As Table 1 shows, POEs were tolerated in the first three years after the Chinese Communist Party (CCP) came to power. But, over the next twenty-nine years, until 1978, these firms were all transformed by the government into SOEs through purchase, squeezing out, or expropriation. By the end of this period, practically all means of production belonged to the state, and the capitalist class had virtually disappeared. In 1978, China started its economic reform by tacitly allowing private control of township and village enterprises (TVEs), but the entrepreneurs had to wear 'red hats' (Chen, 2007). ${ }^{[3]}$ Not until March 1999, when the legislature, the National People's Congress (NPC), amended the constitution to recognize POEs formally as important economic entities and gave them legal status, did it become unnecessary to cloak themselves as TVEs. In other words, POEs operated for quite a while before being legally recognized.

According to the Third National Economic Census conducted by the National Bureau of Statistics, POEs as a percentage of the total number of enterprises ranged from $56.8 \%$ in research and technology services to $73 \%$ in manufacturing. Employment in POEs was lower, ranging from $26.7 \%$ in the transportation, warehousing, and postal services sector to $53.0 \%$ in retail and wholesale.

As of 2011, families controlled $85.4 \%$ of the POEs (China Family Enterprise Development Report, 2011). Some authors have attributed the predominance of this form of business to the long-lasting and deeply embedded influence of Confucianism, which views the family as the fundamental organizing unit of society 
Table 2. Predominance of family firms in selected countries

\begin{tabular}{|c|c|c|}
\hline Country & Year of Study & Role of Family Businesses \\
\hline Australia & 1996 & $70 \%$ of all registered companies are family businesses. \\
\hline Chile & 1994 & $\begin{array}{l}75 \% \text { of all firms and } 65 \% \text { of medium-size to large firms } \\
\text { are family businesses. }\end{array}$ \\
\hline Germany & 1994 & $80 \%$ of all businesses are family businesses. \\
\hline India & 1997 & $\begin{array}{l}75 \% \text { of the } 500 \text { largest companies are family controlled; } \\
\text { of } 297,000 \text { registered businesses nationwide, } 294,000 \\
\text { are family businesses. }\end{array}$ \\
\hline Italy & 1995 & $\begin{array}{l}46 \% \text { of all industrial concerns with at least } 50 \\
\text { employees and almost } 80 \% \text { of businesses that have } \\
\text { between } 20 \text { and } 500 \text { employees are family businesses. }\end{array}$ \\
\hline The Netherlands & 1998 & $\begin{array}{l}80 \% \text { of all businesses and almost } 50 \% \text { of businesses } \\
\text { with } 100 \text { employees or more are family companies. }\end{array}$ \\
\hline Spain & 1995 & $\begin{array}{l}17 \% \text { of the } 100 \text { largest companies, } 23 \% \text { of the } 1,000 \\
\text { largest companies, and } 71 \% \text { of companies with } \\
\text { annual sales of more than } \$ 2 \text { million are family } \\
\text { businesses. }\end{array}$ \\
\hline United Kingdom & 1990 & $76 \%$ of the top 8,000 firms are family companies. \\
\hline
\end{tabular}

Source: Extracted from Upton and Petty (2000).

(Chen et al., 2011). It is also possible that, due to the transitional nature of social, economic, political, and legal institutions in China, managerial opportunism is a more serious problem. As a result, the social capital developed among family members combined with the unique ability of the family to censure its members caused individuals to trust family members more than nonfamily members.

It is difficult to compare this predominance of family businesses to that in other countries because of a lack of consensus over how to distinguish family firms from nonfamily firms. Table 2 presents some statistics organized by Upton and Petty (2000), based on various studies showing family firms as a majority numerically. For other comparisons, Klein (2000) reported that as much as 58\% of German companies and $71 \%$ of Spanish firms were family controlled. Faccio and Lang (2002) reported that 44\% of the publicly listed firms in Europe were family controlled; Anderson and Reeb (2004) estimated that 33\% of the S\&P 500 in the United States can be considered family firms. These various studies were not uniform in how they define a family business, therefore, they should be interpreted qualitatively, rather than quantitatively. It is probably correct, however, to say that the ubiquity of the family form of business organization is not limited to China. Based on the numbers in developed countries, it seems likely that family firms will continue to be important even as China's economy and institutions evolve.

\section{Challenges for Family Firms}

In its social hierarchy, Confucianism does not accord merchants high status. At the top of the social hierarchy was scholars, followed by farmers, craftsmen, and 
merchants. Because merchants were engaged mainly in commerce or trading, they were perceived as not producing any goods themselves and not contributing any value to the economy. That they provided logistical (financing, warehousing, and transporting) and risk-taking (absorbing price fluctuations and uncertain spoilage) services critical to the functioning of the economy was not appreciated. ${ }^{[4]}$ Consequently, the legitimacy of China's private business sector has always faced challenges.

What makes the current situation different is that the political system endorses the dominant presence of SOEs in the economy. First, reforms notwithstanding, some government officials maintain the view that the factors of production should be controlled by the state. Second, many of the family firms were established through management buyouts of SOEs or TVEs. The low prices paid, the opaque sources of the funds used in the buyouts, and the dismissal of workers after the buyouts in order to improve efficiency further clouded perceptions about the legitimacy of POEs. As a result, the term 'original sin' was coined to refer to the acquisition of SOEs and TVEs using these arrangements. Moreover, some continue to believe that the private sector played only an incremental (and maybe even superfluous) role in China's economic transformation - that is, the private sector had simply been implanted into an existing and functioning system. This reluctance to acknowledge the contributions of the private sector might also be bolstered by the fact that many of the private business successes were based on privileged and even illegitimate access to, plus unethical exploitation of, government-controlled resources.

Because of the classical communist philosophy still espoused by a portion of CCP members, the traditional Confucian prejudice against business, the questionable path to controlling ownership, and the reluctance to acknowledge the POEs' contributions to China's economic development, China's POEs have been suppressed by government policy in general and restricted in particular when operating in certain commercial or industrial sectors. This is contrary to the pervasive government support, including favorable tax treatment and subsidies, given to small and medium-size enterprises (SME) and entrepreneurship in developed countries.

\section{STRATEGIES ADOPTED BY GHINESE FAMILY FIRMS}

China's economic development has been extraordinarily rapid, but the disproportionately large influence of family business has been truly remarkable, considering that it took place in an environment that favored SOEs and multinational corporations and perceived family businesses as less legitimate and discriminated against them in terms of access to resources and opportunities. Despite the challenges, family firms now not only dominate the SME sector but also have increasingly gained access to capital markets, becoming large and public companies while successfully holding on to family-dominant ownership and control. 
Mainstream theories proposed by scholars in developed countries about how family firms' unique resources, altruism, socio-emotional wealth, and family entrepreneurship influence their market-oriented competitive advantages and disadvantages in nondiscriminatory market competition can only partially explain this growth because family firm growth during China's transformation period was only partly achieved by market-oriented competition strategy. The nonmarket-oriented social and political network strategy to develop and exploit social relationships (including those with family members, relatives, friends, former classmates, former colleagues, and war buddies) and political connections may have been as critical in the opportunistic growth of Chinese family businesses.

\section{The Nonmarket Social Network Strategy}

Market-oriented growth strategy is based on competitive advantages acquired through innovations, mergers, alliances, internationalization, and so on. But as China transformed, growth opportunities arose from institutional reforms, the creation of new markets because of the relaxation of government control, and changes in government policies. To support enterprise development in the industries that emerged from these opportunities directly and indirectly, the Chinese government then instituted fiscal and other financial policy changes, such as favorable tax policies and export subsidies. New economic agents who wished to take advantage of these opportunities needed resources controlled by the government and its agencies, such as banks and SOEs. For example, the central and local governments could help by providing access to land, making long-term contracts for purchases of goods and services from the new agents, or helping them secure financial capital from banks and SOEs. These transactions between the economic agents and the government were private and, to a large extent, based on political connections and social relationships, instead of arm's-length competitive exchanges in public markets. Therefore, they were nonmarket exchanges.

This is not to say that market strategies did not play an important role; indeed, they formed the underlying structure that the nonmarket strategy needed for sustainability. This is because access to resources and opportunities did not guarantee success in the marketplace. Moreover, an enterprise with competitive advantages flowing from unique technology and knowledge or scale could achieve even higher social status and political identity because size had a direct and positive relationship with market position, social status, and political standing. Furthermore, expansions created employment and raised additional taxes that were part of the local governments' performance measure. As a result, government officials favored POEs that could achieve market success with the favorable treatment the firms received using their nonmarket social and political network strategy. In other words, the success of a family firm's market strategies bred success in the nonmarket strategies and vice-versa in a symbiotic cycle. 


\section{Family Governance as Resource Advantage}

As discussed earlier, family firms have been able to grow disproportionately during the period despite the challenges posed. This suggests strongly that family governance conferred certain advantages in pursuing the competition strategies needed. We discuss three of the most important: family-run firms have lower operating costs, they can respond quickly to market changes, and they can mobilize family members in implementing this nonmarket strategy.

At the early developmental stage of a family business, it typically cannot afford to hire talent in the external labor market; thus, family members form a lowcost talent pool. Second, opportunism is an important source of value dissipation. This could be through the pursuance of managerial self-interest at the expense of the owners or the leakage of trade secrets. Third, the nonmarket social network strategy demands secrecy of information about the political connections and special privileges because leakage of information can quickly cause the business to lose its competitive advantage ( $\mathrm{Li}, 2002)$.

Family firms control this by appointing family members, relatives, or friends to critical positions with strategic importance or information control value, such as finance manager, sales manager, customer service manager, or human resource manager. By doing this, the family can control the allocation of resources, the flow of important market information, and the cost structure. This is a nonmarket strategy in the sense that the most talented individuals in the labor market do not necessarily fill the positions. It sacrifices the incremental effectiveness of the best outside manager (who is presumably more talented than a family member because he or she comes from a larger pool of talent) in exchange for stability, the prevention of internal corruption, and the protection of the firm's trade secrets through the appointment of family members. Otherwise, the firms would have to institute elaborate and costly systems to control potentially dysfunctional behaviors. For these reasons, family firms can operate at a lower cost.

Small and medium-size family firms are often wholly privately owned. In large firms, including publicly traded corporations, absolute control could come from owning more than $50 \%$ of the shares or through a pyramidal ownership structure. Control is also implemented through family members' positions on the board of directors and executive committee. Even among publicly traded companies, the combined share holdings of family members, relatives, and friends, combined with the selection and appointment of friendly directors and managers by the family, easily shifts the balance of power in the family's favor (Luo, Wan, Cai, \& Liu, 2013). Such absolute control allows the family founder to fully realize his/her entrepreneurial potential without undue interference, and it prevents partners and external interested parties from raiding the business. In addition, parental leadership, especially in the founder generation typical during this period, remains most common. The combination of unquestioned primacy and benevolence allowed the family leader to adopt a carrot-and-stick leadership style (Farh \& 
Cheng, 2000), which facilitated resource mobilization, rapid movement, and the agile responses demanded by the market.

Family firms lacked the inherent political connections of the SOEs, so they had to pursue them deliberately and actively. Their businesses, if successful, could exert influence on society as a result of contributions to growth of the gross domestic product (GDP), contributions to government revenues through taxes, and the creation of employment. The firms' charitable donations, involvement in public welfare projects, and the top managers' personal activities in society all added to it. These could then confer political status on the family leader, for example, as a provincial or national advisory committee member, a representative to the NPC, a member of the National Industrial and Commercial Association, or a director of the chamber of commerce. These involvements were, on the surface, about advising the government for the public's benefit. But, through the interactions with government officials, the entrepreneur could have easily built a multilevel political network that gave the family firm advantages in accessing resources and understanding government policies. Political status would also then give the entrepreneur and the business even more legitimacy, a better reputation, and reliable 'behind-the-scenes' support, for example, protection from harassment by other government branches or help in circumventing petty bureaucratic treatment. ${ }^{[5]}$

In addition, family members, relatives, friends, classmates, villagers, and war buddies working in government, banks, and other related agencies became the family's operational collective of connected people. Furthermore, China's cultural tradition of reciprocity then allowed the network to permeate everywhere, reaching through bridging to fill in every structural hole and placing conduits at every node of the social network. Because the connections were associated with the family leader or the family collectively, it was inimitable and immovable and, thus, a source of competitive advantage (Zhang \& Li, 2008).

The family also had multiple means of securing and maintaining the political connections, such as marriage and children's marriage. Families with multiple children could arrange for some of them to enter politics and build a mutually supporting network to control the risks arising from underdeveloped institutions. In this arrangement, the family's business resources gave advantages to family members in politics or working for the government, and those family members then provided support within the government for their families' businesses.

\section{Negative Side of Family Firms' Nonmarket Strategy}

Aside from the purely economic advantages of family governance discussed above, Wong (1985) proposed that familism is an additional uniquely Chinese cultural explanation. Exploiting political connections and social relations to help the family business prosper is deeply embedded in the traditional Chinese cultural and value systems. Familism and social exchange between business and government are deeply rooted in China's tradition. They have always been an important part of resource 
allocation. But what traditional Chinese familism implies in terms of patriarchal supremacy, unity, sacrifice, emotional attachment, and trust may no longer come together in these organizations to form robust social capital. For example, witness the frequent media reports about breakups and quarrels at businesses run by couples, parents and children, siblings, and other family members.

In other words, the tools of voting rights controled by the family, employment of family members, and appointments in key positions have not worked entirely as hoped (Chen et al., 2011). Conflicts with respect to power and interests among family members, especially within extended families, have not been avoided. Gaps and ineffectiveness of the governance structure could make agency costs arising from family member involvement just as high. Even though the controlling family may have been able to claw back from minority shareholders some of the agency costs of professional managers through cost control, lowering of taxes, and tunneling, its competitiveness suffered (Wei, Huang, \& Cheng, 2013). This means that familism may have been an important cultural and institutional resource in family entrepreneurship, but it may be harmful to the long-term growth and sustainability of the family firm. In fact, it may be the force that casts the family business organization asunder.

The family's absolute control renders the other shareholders' monitoring function ineffective in controlling the family's expropriation tendencies. This provides the means by which the family can hold onto disproportionate benefits. In reality, many family firms made no distinction between family and business funds and other resources, grabbing and allocating between the two sides for the families' convenience and for the families' benefit (Wei et al., 2013). Furthermore, unquestioning obedience could have easily run into the great risk arising from hubris and, at times, capricious decision making of the family leader.

But the network had to be assiduously maintained using personal social interactions and exchange. Family leaders then had to spend more time socializing than in management and innovation because the external networks were personal and the family would not trust anyone else to do it.

The social capital built through political connections is gray capital. As Baumol (1990) observed, gray capital can convert entrepreneurial spirit from a productive realm to a destructive nonproductive one. When gray capital is used to secure personal benefit through rent seeking, graft and corruption, and opportunism, it does not increase an enterprise's productive value and only transfers value from one party to another. Yang (2004) stated that this was indeed the case; social capital in the form of political connections and social networks was mostly directed toward nonproductive, value-transferring, and opportunistic exploitation of institutional holes. The impetus for such behavior appears to have been even stronger among family firms because family control and parental leadership made the family firm's behavior involving gray market power and money exchange easier, more dynamic, and more opaque, the last of which is most important to government officials. But their overreliance on nonmarket strategies prevented many of them from investing 
more of their energy and resources in building the strength of their market and innovation strategies.

\section{FUTURE GHALLENGES FOR GHINESE FAMILY FIRMS}

Continued reliance on the growth model adopted by Chinese family firms during the transformation period was greatly challenged by the 2008 financial crisis, and growth based on low labor costs and resource reliance has run into a bottleneck. This is because of the rapidly rising costs of labor, capital, and land, plus restrictions and limitations on raw materials and energy. It is also due to the increasing demands of social responsibility, including environmental sustainability, worker welfare, and social protection. Finally, consumers and the government are paying close attention to product safety and quality. Responding to these developments requires marketoriented strategies that would move businesses to a higher plane of performance. But family firms operate mostly in the traditional sectors, where these problems are especially serious. So, at the same time that they are required to transform themselves, they have to deal with resource shortages, inadequate innovation, succession issues, and business sustainability. Their past bias in favor of nonmarket social network-based strategies will thus present them with even greater challenges.

Several other developments in the environment at Chinese family firms will also require them to transform their competitive strategies. The first is the steady improvement in their favor of China's economic, legal, and social institutions. The continuing development of institutions, the strengthened enforcement of laws, and the increasing orderliness of market competition have all deepened China's transformation into a market economy. Strategies that depend on a nonmarket social network may have a deep and strong social and cultural basis; however, the importance of these strategies over time will wane with institutional developments. In the past few years, market strategies such as innovation and new venture creation have increasingly demonstrated their effectiveness in competition (Li \& Zhang, 2007). Moreover, the effectiveness of political connections has been reduced by the government's anticorruption drive and comprehensive deepening of reforms. Although the influence of political connections is unlikely to completely disappear, their influence will probably slowly weaken.

In a competitive environment that is fair and unbiased, market strategies will become the primary mode of value creation. The external market network is based on cooperation, collaboration, and alliances while the internal social network is about the family's control and governance. The two will become more and more interwoven such that they are inseparable because China is a society of strong ties, and weak ties cannot overcome a lack of trust and effective governance. At the same time, as family businesses expand and internationalize, their external market networks must expand into territories and spheres that cannot be reached by their familism-based social networks. This means that market-oriented cooperation, 
alliance, and coordination will become the mainstream. Familism must then seek an effective consolidation with market contractual principles.

The second is the change in the value proposition. In the previous thirty years, family firms achieved competitive advantage through agile exploitation of opportunities and a low cost of operation. But emerging technologies and globalization are pushing innovation and internationalization to the forefront of family firms' future development. This means that family firms will need more talent and management resources. The familism-based social networks will no longer suffice. Hence, family firms must reorganize by changing the structure of their ownership and control rights to broaden participation. They must introduce professional and international talent to their boards of directors and top management teams. But even more important will be cooperation with banks and other financial institutions, intermediaries, and university research institutions (Guo \& Miller, 2010). This implies that the social network as a nonmarket strategy will perform a mainly complementary, rather than substitute, function, and it will have to serve market-oriented competitive strategies.

The third is that the widespread use of gray capital and political connections may actually create impediments to family firms' long-term growth. One reason is that nonmarket strategies may not easily transition to the succeeding generation. The second generation has commonly received a good education, even higher education in the West, and entertain modern or Western ideas and values about business. As a result, some are unwilling (or unmotivated) or lack the ability to take over and grow the family business using their relationship network. Some have values and business philosophies that conflict with those inherent in nonmarket strategies. It is therefore not difficult to foresee that many successful family businesses, especially those that require the maintenance of multidimensional social relationships, will have no family successor.

\section{THE ARTICLES IN THIS SPEGIAL ISSUE}

The three articles in this Special Issue focus on how formal institutions based on macro-level laws and regulations and the informal institutions based on tradition and culture together have influenced micro-level enterprise strategies. They were selected according to the following process: Seventeen manuscripts were submitted for the issue, and nine were returned after editorial review. The remaining eight were subjected to a first round of double-blind review. Of these, five were judged to be potentially publishable and given the opportunity to be revised and resubmitted. A workshop was then held at Zhejiang University in Hangzhou, China, to discuss how the authors of the five promising manuscripts should respond to the reviewers' and guest editors' comments and suggestions. Two were rejected after the second round of review, leaving three to be put through several more rounds of review before they were accepted. 
Chen, Arnoldi, and $\mathrm{Na}$ (2015) examined intrafamily business group loan guarantees in China. Nonfamily minority shareholder wealth may be expropriated by the controlling families through loans or loan guarantees by family business group listed affiliates (LAF) to other firms within a business group. Such loans are now banned in China, but loan guarantees are not. Even though having a family member serve as the chair of the LAF's board would give the family more control and facilitate this behavior, the controlling families also try to avoid blame for this exploitative practice. As a result, it appears that when the controlling families try to have the LAF guarantee the loans for another firm within the group, the family tends to appoint a nonfamily chair. In fact, the appointment of a family chair or a nonfamily chair interlocked with the apex firm, the firm at the top of the pyramid, is negatively related to the practice. This research contributes to the literature on governance structure and family business by showing that family ties and interlocking ties within business groups can have different effects on organizational behavior - in this case, the appointment of a subsidiary board chair and the exploitation of minority shareholders. Its contribution to the growing concern among scholars of family business about context (Gedajlovic, Carney, Chrisman, \& Kellermanns, 2012) comes from evidence that regional differences in China's institutional development attenuate this behavior.

$\mathrm{Li}, \mathrm{Au}, \mathrm{He}$, and Song (2015) show that philanthropic donations from family businesses are positively related to the controlling family's goal of intrafamily succession. This is hypothesized to be caused by the lengthening of the family's planning horizon and the socio-emotional wealth (Gómez-Mejia, Cruz, Berrone, \& De Castro, 2011) that can be accumulated through philanthropic donations. This relationship, however, is moderated by two factors in China. The social status of the family strengthens the relationship that Li et al. (2015), using expectancy theory, attributes to the family's visibility in the community and, thus, the necessity of maintaining a positive public image and reputation. At the same time, the professed religiosity of the family weakens the relationship. The authors argue that religious families engage in philanthropic activities for intrinsic, compassionate reasons, rather than the instrumental objective of building social capital. Therefore, the intention to have an intrafamily succession seems to have a counterintuitive weaker influence on the religious family's charitable donations. Their results add to growing evidence about the important role played by intrafamily succession intention in distinguishing between concentrated ownership and family ownership - a distinction often difficult to make in empirical studies because most concentrated ownership is by a family - and is a cause of heterogeneity among family-controlled firms. Social status for family business owners and the willingness to profess religiosity openly are both recent developments in China. That they affect family firm behavior adds to the extant evidence about how context influences family business behavior.

Finally, the third paper, by Lu, Liang, Shan, and Liang (2015), observes that institutional constraints in China on geographic expansion may force Chinese 
family firms to internationalize before they are ready. As a result, even though family firm growth tends to be enhanced by asset-based internationalization, their profitability tends to decrease with both asset- and contract-based internationalization. In fact, family dominance of the top management team has significant, negative effects on both growth and profitability. In contrast, having independent directors may help improve profitability. This research again shows that the stage of China's institutional development - domestic barriers to geographic expansion - affects family firm behavior and performance. Importantly, however, it also shows that good corporate governance, even in an institutionally underdeveloped environment or maybe especially so, can have a positive effect on performance. It will be interesting to compare these results with how corporate governance affects the twin performance measures of growth and profitability outside China.

\section{A RESEARGH AGENDA FOR GHINESE FAMILY BUSINESSES}

As the review by Gómez-Mejia et al. (2011) observes, the extant literature on family firms suggests that family firms' pursuance of family-centered noneconomic goals affects strategic choices, such as diversification, internationalization, mergers and acquisition, risk-taking, R\&D expenditures, pollution prevention and control, and the way in which they finance growth. A very important insight in this area is that family-centered non-economic benefits affect family firm behavior and performance in terms of the flow of these benefits and, arguably even more importantly, in terms of the stock of these benefits (the socio-emotional wealth) as a result of the controlling family's loss aversion (Chrisman \& Patel, 2012).

With respect to corporate governance, family firms have been found to differ from nonfamily firms in terms of engaging in excessive altruism to family members (Schulze, Lubatkin, \& Dino, 2003), entering family managers (Gómez-Mejía, Haynes, Núñez-Nickel, Jacobson, \& Moyano-Fuentes, 2007), and having 'rubberstamp' boards (Jones, Makri, \& Gómez-Mejia, 2008).

A research agenda to develop a theory of Chinese family firms should include investigating whether these differences, among others observed outside China, are also exhibited in China. If they are not, then it must be asked which situations and circumstances within China's social, cultural, political, and economic contexts are causing the differences. If they are, then it is important to examine whether the behaviors are driven by the same motivating forces. Research in this direction will test the robustness of the propositions and hypotheses developed by 'nonChinese' research and move the field toward more globally generalizable insights and evidence. In addition, research on the non-economic goals pursued by family firms can enrich the various theories of the firm (e.g., behavioral, agency, resourcebased view, and transaction cost economics).

However, some very basic research questions that are unique to Chinese family firms also require attention. The first is how to define the family firm in China. 
In Western economies, firm owners with the same involvement in and influence on the business differ in their identification of themselves as a family business. For example, some firms owned entirely by a family and managed by it do not think of themselves as family businesses. In contrast, some families consider firms in which they have only minority ownership and no involvement in management family businesses. Family involvement in ownership could be no different from concentrated ownership; governance by the family could be no different from governance by concentrated owners; and management by the family could simply be management by nonfamily concentrated owners. What, then, in addition to a family's involvement, makes a firm a family firm? Consequently, scholars of family businesses have been seeking the family firm's 'essence' (Chrisman, Chua, \& Sharma, 2005). Many scholars have proposed the family's intention of pursuing an intrafamily succession as an important source of the family firm's essence (De Massis et al., 2012). This approach has special relevance in the Chinese context because of the one-child policy. If that one child is unable or unwilling to take over, even though the incumbent family leader and family members of his generation wholly own and manage the business, is the firm a family business? With one child, this situation is likely to arise more frequently than elsewhere. Are businesses controlled by one family generation without potential successor family businesses? Should they be included in empirical studies as family firms?

A second unique research question is related to the fact that, when the family has only a single child, the possibility that the child will be unable or unwilling to take over is high. In Western countries, family firms without family successors will often be sold through management buy-outs (MBO). For example, more than 40\% of the MBOs in the UK are of family firms (CMBOR, 2008). Selling the family business will, however, encounter three serious problems in China. The first is the underdeveloped market for private businesses, which require not only the means of financing the purchases but also the legal framework, valuation expertise, and facilitators, such as business brokers. The second important barrier is the widespread absence of nonfamily managers with executive experience to take over. ${ }^{[6]}$ The third barrier is the possible difficulty of valuing a business whose success depends mainly on the sociopolitical network of the incumbent leader. What is the value of this type of business if the social capital attached to the network is not transferrable? Studying what happens to these family firms without family successors is important for both the families and the Chinese economy because the dissolution of these successful organizations due to the absence of a family successor will be wasteful for both.

A third unique research question concerns the rediscovery of Chinese family business's unique competitive advantages. The nonmarket social network strategy gave family firms unique advantages, not only with respect to overcoming the inadequate institutions and underdeveloped markets but also with lowering internal agency costs in a way that was effective and convenient. But in the future competitive environment, family firms face a new round of value creation through innovation 
and internationalization. How family firms' unique advantages will be created is key to the survival of this form of organization. What this implies is that family firms must convert the advantages of their social networks to develop and support innovation and management capabilities.

A fourth unique research question is about quanxi. As discussed previously, the role and uses of guanxi may have to change as China's economy moves further toward market liberalization. Will family and nonfamily firms respond differently? What will be the consequences of these adaptive differences? The nature, role, importance and exploitation of guanxi in China's economic development have been studied extensively by management scholars (e.g., Chen, Chen, \& Huang, 2013; Fu, Tsui, \& Dess, 2006; Guo \& Miller, 2010; Park \& Luo, 2001; Tsui \& Farh, 1997; Xin \& Pearce, 1996). Because most of the POEs studied are likely family controlled, the behavioral and performance impacts on guanxi of family involvement must already be embedded in the observations made by researchers. But they have not been studied explicitly in terms of whether and how they are influenced by family involvement rather than, for example, by concentrated ownership.

A fifth unique research question is to examine alternative explanations for Chinese family firms' successful competition. In a recent paper, Luo and Child (2015) proposed compositional capabilities (CG) as a way for Chinese family firms with ordinary resources to develop competitive advantages through lower cost, faster responses to market conditions, and network intelligence. These advantages overlap with the observations made here about how Chinese family firms, in fact with disadvantages in tangible resources, have competed successfully. Instead of CC, we have attributed these advantages to common interests and trust among family members. Are CGs related to family control and are they enhanced or impeded by family control? How much of the CGs and under what conditions do they survive the founding entrepreneur generation? Are the competitive advantages due to $\mathrm{CG}$ sustained better in family firms than in nonfamily firms?

\section{GONGLUSION}

The particular circumstances in China do not exist in the developed Western European and North American countries; therefore, the strategic adaptations made by family firms in China may not have direct implications for family firms in those countries. Nevertheless, this locally focused research can still make contributions by adding to the evidence about the economic and non-economic goals pursued, agency issues faced by family owners and other stakeholders, the role played by family resources, dynamics, and politics in promoting entrepreneurship, motivations for and behavioral patterns in corporate social responsibility-oriented activities, and, especially as a result of China's one-child policy, organizational transitions when the controlling family has limited choices or no family successor. Ultimately, the most important question is, of course, whether and how this research can transcend these special circumstances and provide insights that are generally 
applicable to family firms in the rest of the world. In this way, scholars of Chinese family business will be contributing not only to a theory of Chinese family business governance and management but also to a globally applicable theory of the family firm. We, the guest editors, hope that this Special Issue will help in a small way to catalyze research with those objectives and add greatly to our understanding of this unique form of business enterprise.

\section{SUPPLEMENTARY MATERIAL}

To view supplementary material for this article, please visit http://dx.doi.org/ $10.1017 /$ mor. 2015.60

\section{NOTES}

[1] Here, China includes mainland China, Taiwan, Hong Kong, and Macau, which have different institutions and business environments. The social, political, and economic environment that we discuss do not apply to Chinese family firms operating outside mainland China. A more accurate term would have been mainland Chinese family firms, but we abbreviate it as Chinese family firms.

[2] Although declines in the number of offspring also occur in the West, the difference is that in China it is imposed by law.

[3] To 'wear a red hat' means professing to be a dedicated communist, whose activities follow communist principles and serve the interests of the people and the CCP.

[4] The importance of these services is demonstrated in India, where, for lack of such services, a large proportion of farm products spoil before reaching the market.

[5] $\mathrm{Li}$ and Liang (forthcoming) propose that successful entrepreneurs' pursuit of political appointments in China may not be entirely self-serving and may involve fulfilling a Confucian obligation to serve society.

[6] This observation came from a representative at the China office of a Western brokerage firm when asked why the $\mathrm{MBO}$ market in China is underdeveloped.

\section{REFERENGES}

Anderson, R., \& Reed, D. 2004. Board composition: Balancing family influence in S\&P 500 firms. Administrative Science Quarterly, 49: 209-327.

Baumol, W. J. 1990. Entrepreneurship: Productive, unproductive, and destructive. Journal of Political Economy, 98, pt. 1: 893-921.

Chen, G. C., Chen, X. P., \& Huang, S. S. 2013. Chinese guanxi: An integrative review and new directions for future research. Management and Organization Revieze, 9(1): 167-207.

Chen, C. J. P., Li, Z., Su, X., \& Sun, Z. 2011. Rent-seeking incentives, corporate political connections and the control structure of private firms: Chinese evidence. Journal of Corporate Finance, 17: 229-243.

Chen, W. 2007. Does the colour of the cat matter? The red hat strategy in China's private enterprises. Management and Organization Reviez, 3(1): 55-80.

Chen, X., Arnoldi, J., \& Na, C. H. 2015. Governance structure and related party loan guarantees: The case of Chinese family business groups. Management and Organization Reviez, 11 (4): 599-619.

China privately operated economy research association family business research group. 2011. Report on China Family Business Development. Beijing: Zhongxin. (In Chinese.)

Chrisman, J. J., Chua, J. H., \& Sharma, P. 2005. Trends and directions in the development of a strategic management theory of the family firm. Entrepreneurship Theory and Practice, 29: $555-576$. 
Chrisman, J.J., \& Patel, P. J. 2012. Variations in R\&D investments of family and non-family firms: Behavioral agency and myopic loss aversion perspectives. Academy of Management Journal, 55: 976-997.

GMBOR. 2008. Trends in buyouts in the UK. Management buyouts: Quarterly revieze from the Centre for Management Buyout Research. Nottingham, UK: Center for MBO Research/University of Nottingham.

De Massis, A., Sharma, P., Chua, J. H., \& Chrisman, J. J. 2012. Family business studies: An annotated bibliography. London: Edward Elgar.

Faccio, M., \& Lang, L. H. P. 2002. The ultimate ownership of Western European corporations. Journal of Financial Economics, 65: 365-395.

Farh, J. L., \& Cheng, B. S. 2000. A cultural analysis of paternalistic leadership in Chinese organizations. In J. T. Li, A. S. Tsui, \& E. Weldon (Eds.), Management and Organizations in the Chinese Context. London: MacMillan.

Fu, P. P., Tsui, A. S., \& Dess, G. 2006. The dynamics of guanxi in Chinese high-tech organizations: Implications for knowledge management and decision-making. Management International Revieze, 3(1): 1-29.

Gedajlovic, E., Carney, M., Chrisman, J. J., \& Kellermanns, F. W. 2012. The adolescence of family firm research: Taking stock and planning for the future. Journal of Management, 38: 1010-1037.

Gómez-Mejía, L., Cruz, C., Berrone, P., \& De Castro, J. 2011. The bind that ties: Socioemotional wealth preservation in family firms. Academy of Management Annals, 5 : $653-707$.

Gómez-Mejía, L. R., Haynes, K. T., Núñez-Nickel, M., Jacobson, K. J. L., \& Moyano-Fuentes, J. 2007. Socioemotional wealth and business risk in family-controlled firms: Evidence from Spanish olive oil mills. Administrative Science Quarterly, 52: 106-137.

Guo, C., \& Miller, J. K. 2010. Guanxi dynamics and entrepreneurial firm creation and development in China. Management and Organization Revieze, 6(2): 267-291.

Hawksworth, J., \& Tiwari, A. 2011. The World in 2050. The accelerating shift in global economic power: Challenges and opportunities. London: PricewaterhouseCooper Economics.

International Monetary Fund. 2014. World Economic Outlook Database 2014: Report for Selected Countries and Subjects.

Jones, C. D., Makri, M., \& Gómez-Mejía, L. R. 2008. Affiliate directors and perceived risk bearing in publicly traded, family-controlled firms: The case of diversification. Entrepreneurship Theory and Practice, 32: 1007-1026.

Klein, S. B. 2000. Family businesses in Germany: Significance and structure. Family Business Reviere, 13: 157-182.

Li, H., \& Zhang, Y. 2007. The role of managers' political networking and functional experience in new venture performance: Evidence from China's transition economy. Strategic Management Journal, 28: 791-804.

Li, W. W., Au, K., He, A., \& Song, L. H. 2015. Intra-family succession intention and corporate philanthropy: Expectancy and socio-emotional wealth perspectives. Management and Organization Revieze, 11(4): 621-644.

Li, X. C. 2002. Trust, loyalty and familism paradox. Management World, 6: 87-93. (In Chinese.)

Li, X. H., \& Liang, X. Y. Forthcoming. A Confucian social model of political appointments among private entrepreneurs. Academy of Management Journal. Available online at: http://amj.aom.org/content/early/2014/09/11/amj.2012.1067.full.pdf+html

Lu, J. W. Z., Liang, X. J., Shan, M. M., \& Liang, X. Y. 2015. Internationalization and performance of China's family firms: The moderating role of corporate governance. Management and Organization Revieze, 11(4): 645-678.

Lumpkin, G. T., Steier, L., \& Wright, M. 2011. Strategic entrepreneurship in family business. Strategic Entrepreneurship Journal, 5: 285-306.

Luo, W., Wan, D. F., Cai, D., \& Liu, H. 2013. Multiple large shareholder structure and governance: The role of shareholder numbers, contest for control, and formal institutions in Chinese family firms. Management and Organization Revieze, 2(2): 265-294.

Luo, Y., \& Child, J. 2015. A composition-based view of firm growth. Management and Organization Revieze, 11(3): 379-411.

Mishra, C. S., \& McConaughy, D. C. 1999. Founding family control and capital structure: The risk of loss of control and the aversion to debt. Entrepreneurship Theory and Practice, 23: 53-65. 
National Bureau of Statistics. 2014. Third National Economic Census. Beijing: National Bureau of Statistics of China.

Park, S. H., \& Luo, Y. 2001. Guanxi and organizational dynamics: Organizational networking in Chinese firms. Strategic Management Journal, 22: 455-477.

Schulze, W. G., Lubatkin, M. H., \& Dino, R. N. 2003. Toward a theory of agency and altruism in family firms. Journal of Business Venturing, 18: 473-490.

Tsui, A. S., \& Farh, L. J. 1997. Where guanxi matters: Relational demography and guanxi in the Chinese context. Work and Occupations, 24: 56-79.

Tsui, A. S., Bian, Y., \& Cheng, L. (Eds.) 2006. China's domestic private firms: Multidisciplinary perspectives on management and performance. Armonk, NY: M.E. Sharpe.

Upton, N., \& Petty, W. 2000. Venture capital investment and US family business. Venture Capital, 2: 27-39.

Wei, M. H., Huang, Q. Y., \& Cheng, M. Y. 2013. The family-related majority shareholder's role in governance: From the perspective of related party transactions. Management World, 3: 133-147. (In Chinese.)

Wong, S. L. 1985. The Chinese family firm: A model. British Journal of Sociology, 36(1): 58-72.

Xin, K. R., \& Pearce, J. 1996. Guanxi: Connections as substitutes for formal institutional support. Academy of Management Journal, 39: 1641-1658.

$\mathrm{Xu}$, G. 2010. State-owned enterprises in China: How big are they? [Cited 23 August 2015]. Available from URL: http://blogs.worldbank.org/eastasiapacific/state-ownedenterprises-in-china-how-big-are-they/

Yang, K. 2004. Institutional holes and entrepreneurship in China. Sociological Review, 52: $371-$ 389.

Zhang, S. J., \& Li, X. C. 2008. Managerial ties, firm resources, and performance. Asia Pacific Journal of Management, 25: 615-633.

Xin Chun Li (mnslxc@mail.sysu.edu.cn) is a professor of strategic management and entrepreneurship at Sun Yat-sen University, Guangzhou, China, and director of its Chinese Family Firm Research Centre. He was dean of the Sun Yat-Sen Business School between 2004 and 2010, an advisory board member of the International Association for Chinese Management Research, and a member of the editorial advisory board of several Chinese journals. He has published over 60 academic papers in Chinese and international journals on strategic alliances, family business, and entrepreneurship.

Ling Chen (ietlchen@zju.edu.cn) is a professor of family business and business history, School of Management, Zhejiang University, Hangzhou, China. He received a $\mathrm{PhD}$ in economics from Humboldt University, Berlin, Germany. His main research areas include family business succession, governance, and comparative business history. He has published eight books and over 70 articles in academic journals in Chinese and English. He is on the editorial board of several Chinese and international journals.

Jess Chua (jess.chua@haskanye.calgary.ca) is a professor of family business at the Haskayne School of Business of the University of Calgary, Canada; professor of family business at the Lancaster University Management School, University of Lancaster, UK; and Pao Yu Kong Professor of Family Business at the School of Management of Zhejiang University, Hangzhou, China. His main research areas are family business governance and entrepreneurial finance. He received a $\mathrm{PhD}$ in finance from the University of Michigan. 
Bradley L. Kirkman (blkirkman@ncsu.edu) is the General (Ret.) H. Hugh Shelton Distinguished Professor of Leadership and Department Head of the Management, Innovation, and Entrepreneurship Department in the Poole College of Management at North Carolina State University. He received a $\mathrm{PhD}$ in organizational behavior from the Kenan-Flagler Business School at the University of North Carolina at Chapel Hill. His research focuses on leadership, international management, virtual teams, and work team leadership and empowerment.

Sara Rynes (sara-rynes@uiowa.edu) holds the Tippie-Rollins Chair in Excellence at the University of Iowa's Tippie College of Business. Her research interests are in academic-practitioner relations, human resource strategy, compensation, recruitment, and management education. She is a Fellow of the Academy of Management, the American Psychological Association, the Management Education Research Institute, and the Society for Industrial and Organizational Psychology. Her PhD in industrial relations is from the University of Wisconsin-Madison.

Luis Gómez-Mejía (lgomezme@nd.edu) is the Ray and Milan Siegfried Professor of Management at the University of Notre Dame. His research has been cited more than 18,000 times and has received the most prestigious awards, including best paper in the Academy of Management Fournal, best paper in Administrative Science Quarterly, and highest-impact paper from the Entrepreneurship Division of the Academy of Management. He is a member of the Hall of Fame of the Academy of Management. 